\title{
Pre-project geoecological studies for clearing of the Tikhomandritsa riverbed (Tver Region, Russia)
}

\author{
Fedor F. Bryukhan ${ }^{1, *}$ \\ ${ }^{1}$ Moscow State University of Civil Engineering, Yaroslavskoe shosse, 26, Moscow, 129337, Russia
}

\begin{abstract}
Pre-project geoecological studies were carried out in autumn 2015 along the entire length of the Tikhomandritsa river, in Navolok lake waters near the river source and Udomlya lake near its mouth, as well as on the territory adjacent to the river, as part of the Comprehensive Engineering Surveys. The aim of the studies was to obtain initial data to assess the current ambient conditions of the study area, as well as to develop the project of cleaning the upper stretch of the Tikhomandritsa riverbed and spillway structure construction. Water, bottom sediments and soil contamination levels were identified. It is found that the water quality in the studied water bodies belongs to the contaminated category. Bottom sediments at the upper stretch of the river up to a distance of $2.5 \mathrm{~km}$ from its source are pure and can be used in agriculture without restrictions. Bottom sediments samples taken at a distance of $5.5 \mathrm{~km}$ from the river source and its mouth contain dangerous level of coliform bacteria. Basing on the territory survey a tree and shurberry felling plan was drawn up and the volume of works of the river purification was determined. The project implementation will help to increase the river flow in dry water years, increase its self-cleaning velocity and environmental improvement of the area. In addition, the increase of water flow into Udomlya lake will provide Kalinin NPP with additional water resources for its process water supply. The conceptual scheme of this study is largely applicable for the basins of other small rivers.
\end{abstract}

\section{Introduction}

The Tikhomandritsa river outflowing from Navolok lake, flows south-south-westwards into Udomlya lake. Kezadra lake is located to the east of Navolok lake. These water bodies included in the Baltic Sea basin are located in Udomlya district of Tver Region near the Kalinin NPP. According to [1, 2], these lakes are of glacial origin.

The Comprehensive Engineering Surveys performed on the Tikhomandritsa river, water areas of Navolok lake near the river head and Udomlya lake near its mouth, as well as on the adjacent to the river earth's surface in autumn and winter 2015 specialists of Scientific \& Industrial Association Gidrotekhproekt (Valdai, Novgorod region, Russia) and

*Corresponding author: pniiis-gip@mail.ru 
Engineering Servey and Geo-ecology Department of the Moscow State University of Civil Engineering. The aim of works was to obtain initial data to assess the current ambient conditions of the study area, as well as to develop the project of cleaning the upper 1400 meters stretch of the Tikhomandritsa riverbed and spillway structure construction.

In dry water years Udomlya lake recharge from Kezadra lake is planned: first by pumping water through a pipeline into Navolok lake and then by gravity down the Tikhomandritsa river. An additional water flow into Udomlya lake will provide the Kalinin NPP with additional water resources for its process water supply. It must be emphasized that the adequacy of water resources is one of the NPP safety conditions [3, 4]. To maintain household-level water in Navolok lake at the beginning of the riverbed channel to be cleared the construction of controlled spillway structure is planned. Its construction is projected in the swamp area with peat thickness up to 3-7 meters. In front of spillway the construction of silt trap (pit) with dimensions of $25 \times 55 \mathrm{~m}$ in plan view and depth to mineral soil is provided.

Thus, the implementation of the project of clearing the upper stretch of the river in addition to the environmental impact when using the area for domestic, recreational purposes and agricultural land quality improvement provides for the increase of water flow into Udomlya lake in dry water years.

\section{Brief description of the territory natural conditions}

The area is mostly medium and gently rolling glacial plain, folded by moraine. River and gully erosion is represented in the study area.

The area is characterized by high-contrast of geochemical conditions. This is due primarily to the heterogeneity of terrain and surface deposits. Various genetic land forms, characterized by different earth's surface slopes of different depth and breakdown granularity are present in this area. Therefore, various conditions of moisture redistribution, mechanical and chemical denudation, leaching, migration and accumulation of chemical elements and their compounds are created in the landscapes [5].

Soddy-podzolic soils of different degree of podzolization and swamp and swamppodzolic soils prevail in the soil cover. At the same time, the soil cover of the area is characterized by high complexity due to the heterogeneity of parent rocks, relief variety and moisture conditions [1]. In modern Tikhomandritsa river valleys floodplain sod-gley soils are usually developed.

According to the general map of the territory of Russia for the construction of [6] the study area belongs to the climatic subregion II-B. The climate is moderate continental, characterized by the transitional features from the continental climate of the eastern regions of European part of Russia to the more humid climate of the north-western regions. It is characterized by a relatively warm summer and moderately cold winter with stable snow cover and well defined mid-seasons. The amount of precipitation and its patterns are mainly due to cyclonic activity.

Rivers belong to the predominantly snow-fed (about 60\%) and underground (20-25\%) and rain (15-20\%) low land type [5]. High spring tide, low summer-autumn mean water level and stable winter mean water level are characteristic for the rivers regime. The spring tide level rise usually begins in late March - early April. For rivers of the study area are characterized by the single-peak flood, but there are several peaks of levels rise in some years $[1,5]$.

The Tikhomandritsa river takes away waters from Navolok lake and falls into Udomlya lake. The river is $9 \mathrm{~km}$ long and catchment basin $-116 \mathrm{~km}^{2}$. Initial $1.2 \mathrm{~km}$ it flows in the peat and sapropelic river channel. In the middle and lower course the channel is circuitous. According to hydrological studies data conducted by Scientific \& Industrial Association 
Gidrotekhproekt, the channel width ranges from 5 to $7 \mathrm{~m}$, pool depth is $0.5-0.7 \mathrm{~m}$, cripple about $0.3 \mathrm{~m}$. At the last kilometer the channel has a drop in height up to $4 \mathrm{~m}$. Figure 1 shows river photographs in its upstream and downstream.

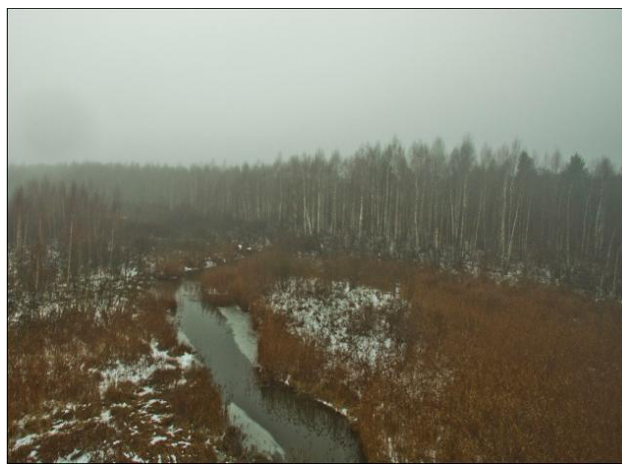

a)

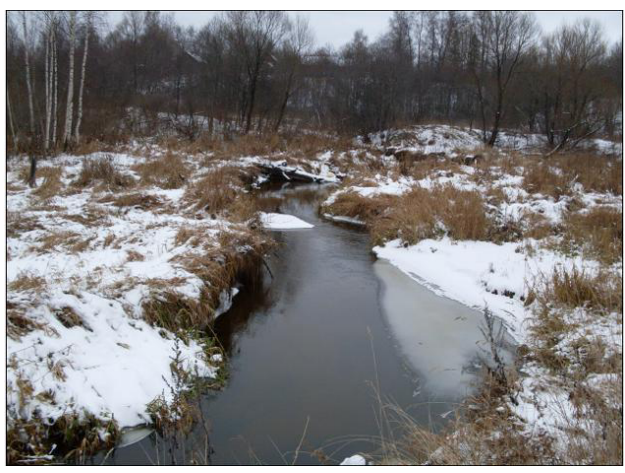

b)

Fig. 1. Tikhomandritsa river in its upper (a) and lower (b) course.

The deepest part of Navolok lake basin, from which the river flows is near its origin [1]. This basin lies of narrow trench beneath the riverbed over $1200 \mathrm{~m}$ with a depth of incision in the loam of 4 to $7.5 \mathrm{~m}$. Currently this trench is completely filled with peat and sapropel. Sapropelic and peat deposits in the lakes of glacial origin in the region began to form 8-11 thousand years ago [7]. Such deposits are highly useful organic fertilizer and soil ameliorant $[8,9]$.

The area in the Tikhomandritsa river basin is partly swampy. River valleys and flowing into it small streams have a characteristic branching pattern in plan view, their cross-section is developed poorly. However, floodplains are clearly visible.

\section{Engineering and Environmental Surveys procedure and outline}

As part of the Engineering and Environmental Surveys carried out in accordance with [10, 11], the following works were performed:

- Collection and analysis of file materials on the ambient conditions of study area.

- Reconnaissance area survey, visual detection of sources and signs of contamination.

- Water, bottom sediments and soil samples collection.

- Laboratory analysis of samples.

- Water bodies and adjacent to the Tikhomandritsa river land area contamination assessment.

- Development of recommendations to improve the Tikhomandritsa river capacity, environmental and sanitary conditions of the area.

The studies were carried out across the entire river length, in Navolok lake waters near the river head and Udomlya lake near the river mouth, as well as on the adjacent to the river earth's surface near the banks.

Reconnaissance area survey was carried out with the use of a radio-controlled quadrocopter equipped with a video camera.

No evidence of the river contamination was found from its head to Kaskovo village located $6 \mathrm{~km}$ downstream from the head. Starting from it, up to the bridge over the the Tikhomandritsa river (approximately $0.5 \mathrm{~km}$ from the river mouth), pronounced 
contamination spots of water surface are observed caused by agricultural facilities discharges and domestic sewage.

Water samples were collected from Navolok lake of two stagnant zones and beyond, from Udomlya lake near the river mouth and from the river at its various sites. Bottom sediments sampling is made from Navolok lake near the river head, from the river itself and Udomlya lake near its mouth. Soil samples were collected on the left and right banks of the river at a distance of 30 meters from the water's edge. The sampling points are shown in Figure 2 .

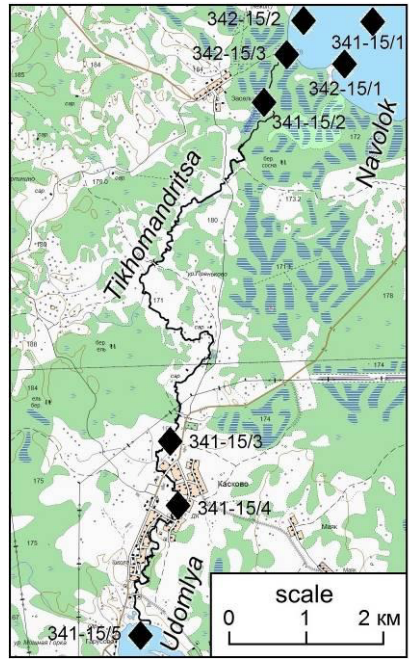

a)

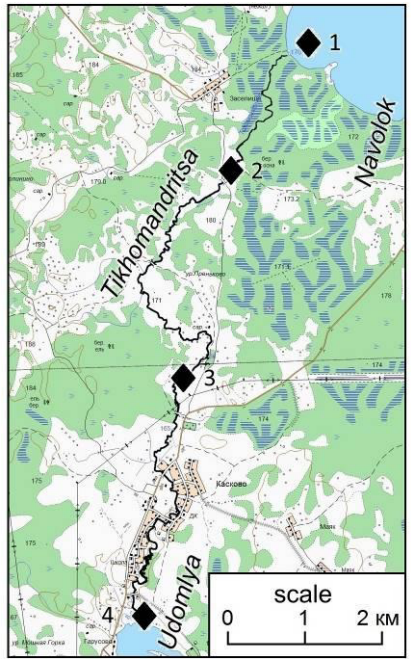

b)

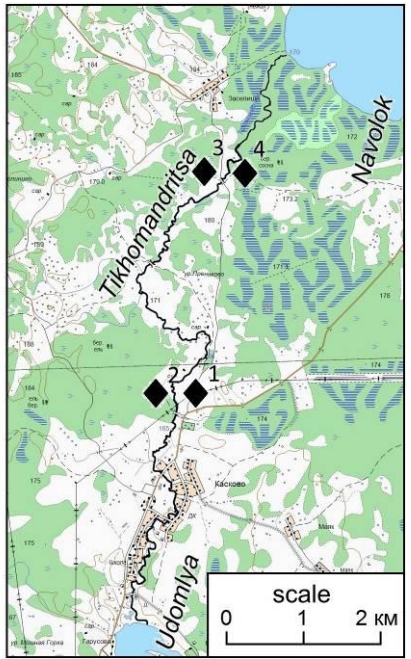

c)

Fig. 2. Sampling points: a) - water, b) - bottom sediments, c) - soil.

Water, bottom sediments, soil samples collection and their storage was carried out in accordance with current Russian standards [12-14], and laboratory studies - in accordance with the procedures set out in [15-19]. It should be noted that for at least the last twenty years a lot of work is carried out in Russia on the harmonization of national and international environmental standards, including in the field of Engineering Surveys [20].

Quantitative chemical analysis of water samples were carried out at the Environmental Protection Laboratory of the Kalinin NPP. Bottom sediments and soil samples analyses, which provided for the physico-chemical, microbiological and parasitological studies were carried out in the Hygiene and Epidemiology Laboratory Center No 141 (Udomlya, Tver Region).

\section{Results and discussion}

Based on the area survey a plan of felling of the tree and shrubbery was drawn up and the volume of works of the river purification was determined. According to the performed survey, it was found that a small area of 1.55 ha where trees and shrubs grow, as well as single trunks of willow, alder and birch in the defective condition is under the plan.

Two land plots were also selected near the river banks with a total area of about 2.8 ha for temporary storage and drying of extracted sapropel and peat.

The laboratory quantification analyses results of water samples selected from water bodies under study are presented in Table 1. 
Table 1. Quantitative water samples chemical analyses results.

\begin{tabular}{|l|c|c|c|c|c|c|c|c|}
\hline \multirow{2}{*}{ Indicators } & \multicolumn{7}{|c|}{ Samples numbers (according to the map $\boldsymbol{a}$ in Figure 2 ) } \\
\cline { 2 - 10 } & $\begin{array}{c}341- \\
15 / 1\end{array}$ & $\begin{array}{c}342- \\
15 / 1\end{array}$ & $\begin{array}{c}342- \\
15 / 2\end{array}$ & $\begin{array}{c}342- \\
15 / 3\end{array}$ & $\begin{array}{c}341- \\
15 / 2\end{array}$ & $\begin{array}{c}341- \\
15 / 3\end{array}$ & $\begin{array}{c}341- \\
15 / 4\end{array}$ & $\begin{array}{c}341- \\
15 / 5\end{array}$ \\
\hline Temperature, ${ }^{\circ} \mathrm{C}$ & 0.5 & 3.1 & 4.9 & 2.9 & 0.3 & 0.2 & 0.3 & 0.7 \\
\hline $\mathrm{pH}$ & 7.55 & 7.54 & 7.78 & 7.67 & 7.60 & 7.75 & 7.54 & 7.57 \\
\hline Nitrate Ion, $\mathrm{mg} / \mathrm{dm}^{3}$ & 0.57 & 0.57 & 0.75 & 0.73 & 0.59 & 0.76 & 0.73 & 0.73 \\
\hline Nitrite Ion, $\mathrm{mg} / \mathrm{dm}^{3}$ & $<0.02$ & $<0.02$ & $<0.02$ & $<0.02$ & $<0.02$ & $<0.02$ & $<0.02$ & $<0.02$ \\
\hline $\begin{array}{l}\text { Ammonium Ion, } \\
\mathrm{mg} / \mathrm{dm}^{3}\end{array}$ & 0.74 & 0.74 & 0.77 & 0.78 & 0.59 & 0.91 & 0.92 & 0.81 \\
\hline Total BOD, $\mathrm{mg} \mathrm{O}_{2} / \mathrm{dm}^{3}$ & 5.1 & 4.3 & 5.2 & 4.9 & 5.3 & 5.2 & 5.3 & 13.2 \\
\hline $\mathrm{COD}, \mathrm{mg} \mathrm{O}_{2} / \mathrm{dm}^{3}$ & 56 & 75 & 62 & 62 & 60 & 58 & 57 & 55 \\
\hline
\end{tabular}

Table 1 shows that $\mathrm{pH}$ of water, and the content of nitrate ions and nitrite ions in all water bodies under study correspond to norm. TLV excess rate by ammonium ion, total biological oxygen demand (total BOD) and chemical oxygen demand (COD) are 1.18-1.62, $1.43-4.40,1.83-2.50$, respectively. According to the criteria [21], the water quality in Navolok lake, Tikhomandritsa river and Udomlya lake falls under contaminated category.

Laboratory tests of bottom sediments and soils samples provide for their physicochemical, microbiological and parasitological studies. The test results are presented in Tables 2 and 3.

Table 2.Sampling data of bottom sediments.

\begin{tabular}{|c|c|c|c|c|}
\hline \multirow{2}{*}{ Indicators } & \multicolumn{4}{|c|}{ Samples numbers (according to the map $\boldsymbol{b}$ in Figure 2) } \\
\hline & 1 & 2 & 3 & 4 \\
\hline \multicolumn{5}{|c|}{ Physical and chemical studies } \\
\hline $\mathrm{pH}$ of salt extract & $5.6 \pm 0.1$ & $5.4 \pm 0.1$ & $6.2 \pm 0.1$ & $6.1 \pm 0.1$ \\
\hline Nitrate nitrogen, $\mathrm{mg} / \mathrm{kg}$ & $<2.80$ & $<2.80$ & $<2.80$ & $<2.80$ \\
\hline Ammonium nitrogen, $\mathrm{mg} / \mathrm{kg}$ & $<5.0$ & $<5.0$ & $<5.0$ & $<5.0$ \\
\hline Petroleum products, $\mathrm{mg} / \mathrm{kg}$ & $<50$ & $<50$ & $<50$ & $<50$ \\
\hline Chlorides, $\mathrm{mg} / \mathrm{kg}$ & $3.55 \pm 0.18$ & $6.39 \pm 0.32$ & $4.62 \pm 0.23$ & $2.49 \pm 0.12$ \\
\hline Sulphates, $\mathrm{mmol} / 100 \mathrm{~g}$ & $2.37 \pm 0.33$ & $1.84 \pm 0.26$ & $<1$ & $<1$ \\
\hline Iron (a bulk content), $\mathrm{mg} / \mathrm{kg}$ & $2352 \pm 706$ & $1670 \pm 501$ & $1581 \pm 474$ & $1287 \pm 386$ \\
\hline Iron (a mobile form), $\mathrm{mg} / \mathrm{kg}$ & $600 \pm 180$ & $368 \pm 111$ & $38 \pm 12$ & $40 \pm 12$ \\
\hline \multicolumn{5}{|c|}{ Microbiological studies } \\
\hline Coliform index & 10 & 10 & 100 & 1000 \\
\hline Enterococcus index & $<10$ & $<10$ & $<10$ & $<10$ \\
\hline Pathogenic bacteria & not detected & not detected & not detected & not detected \\
\hline Shigella & not detected & not detected & not detected & not detected \\
\hline \multicolumn{5}{|c|}{ Parasitological studies } \\
\hline Eggs and larvae of helminths & not detected & not detected & not detected & not detected \\
\hline Cysts of pathogenic entericprotozoa & not detected & not detected & not detected & not detected \\
\hline
\end{tabular}


Table 3.Sampling data of soil.

\begin{tabular}{|c|c|c|c|c|}
\hline \multirow{2}{*}{ Indicators } & \multicolumn{4}{|c|}{ Samples numbers (according to the map $c$ in Figure 2) } \\
\hline & 1 & 2 & 3 & 4 \\
\hline \multicolumn{5}{|c|}{ Physical and chemical studies } \\
\hline $\mathrm{pH}$ of salt extract & $5.4 \pm 0.1$ & $5.8 \pm 0.1$ & $4.7 \pm 0.1$ & $5.3 \pm 0.1$ \\
\hline Nitrate nitrogen, $\mathrm{mg} / \mathrm{kg}$ & $<2.80$ & $3.12 \pm 0.78$ & $22.73 \pm 5.68$ & $8.26 \pm 2.07$ \\
\hline Ammonium nitrogen, $\mathrm{mg} / \mathrm{kg}$ & $<5.0$ & $<5.0$ & $<5.0$ & $<5.0$ \\
\hline Petroleum products, $\mathrm{mg} / \mathrm{kg}$ & $<50$ & $<50$ & $<50$ & $<50$ \\
\hline Chlorides, $\mathrm{mg} / \mathrm{kg}$ & $5.68 \pm 0.28$ & $9.94 \pm 0.50$ & $3.20 \pm 0.16$ & $2.13 \pm 0.11$ \\
\hline Sulphates, $\mathrm{mmol} / 100 \mathrm{~g}$ & $<1$ & $<1$ & $<1$ & $<1$ \\
\hline Iron (a bulk content), $\mathrm{mg} / \mathrm{kg}$ & $2398 \pm 720$ & $583 \pm 175$ & $8793 \pm 2638$ & $4280 \pm 1284$ \\
\hline Iron (a mobile form), $\mathrm{mg} / \mathrm{kg}$ & $86 \pm 26$ & $286 \pm 86$ & $250 \pm 75$ & $105 \pm 31$ \\
\hline \multicolumn{5}{|c|}{ Microbiological studies } \\
\hline Coliform index & 10 & 10 & $<10$ & 10 \\
\hline Enterococcus index & $<10$ & $<10$ & $<10$ & $<10$ \\
\hline Pathogenic bacteria & not detected & not detected & not detected & not detected \\
\hline Shigella & not detected & not detected & not detected & not detected \\
\hline \multicolumn{5}{|c|}{ Parasitological studies } \\
\hline Eggs and larvae of helminths & not detected & not detected & not detected & not detected \\
\hline Cysts of pathogenic entericprotozoa & not detected & not detected & not detected & not detected \\
\hline
\end{tabular}

As part of the physico-chemical studies of bottom sediments and soil samples $\mathrm{pH}$ value was determined by a salt extract, and the content of nitrate nitrogen, ammonia nitrogen, oil products, chlorides, sulfates, iron. All 4 samples of bottom sediments and 3 samples of soil fall under slightly acidic category, 1 soil sample - medium acidic category. There is high content of nitrite nitrogen in soil samples No. 3 and 4. The iron content in the soil and bottom sediments corresponds to the background values for the European Russia [22]. According to the most key indicators bottom sediments in the Tikhomandritsa river stretch from its head up to a distance of 2.5 kilometers, according to [23] belong to the category of pure. Therefore, bottom sediments from this stretch, which dry weight is about $9600 \mathrm{t}$ may be used without limitation, and in particular as fertilizer for soil. Bottom sediments samples No. 3 and 4 collected at a distance of $5.5 \mathrm{~km}$ from the Tikhomandritsa river head and its mouth contains dangerous level of coliform bacteria. This is due to the wastewater discharge from agricultural facilities and domestic sewage from Kaskovo village.

More detailed chemical analyses of bottom sediments enable the use of their geochemical characteristics as indicators of technogenic state of river basins [24].

Extraction of silt from the river stretch to be cleared and its transportation will be carried out by the dredger. After silt drying on selected land plots it can be used as fertilizer for agricultural land.

Implementation of the project of clearing the upper stretch of the Tikhomandritsa riverbed from bottom sediments, aquatic vegetation and household waste will help to improve the ecological state of the river and surrounding area. According to calculations made by Scientific \& Industrial Association Gidrotekhproekt specialists the annual flow of the Tikhomandritsa river in Udomlya lake for dry water years ( 90 percent exceedance) is 16.2 MCM. As a result of water transfer from Kezadra lake in dry water years and 
regulation of the river flow in dry water years, additional annual water inflow in Udomlya lake is up to $12.5 \mathrm{MCM}$. This fact also will positively affect the ecological state of the river, because it is known that with increase of flow rate the self-cleaning velocity of rivers rises and their water quality improves $[25,26]$. Another favorable factor is the aquatic vegetation growth inhibition by increasing the flow and flow velocity. Besides, the significant flow and flow velocity increase will result in bottom sediments washoff in the middle and lower river stretch.

As has already been mentioned, in addition to the obvious environmental effect the implementation of the project of clearing the upper stretch of the riverbed and its flow regulation, will provide Kalinin NPP with additional water inflow in dry water years.

It may be noted that the conceptual scheme of this study is largely applicable in the geoecological studies of other minor river basins.

\section{Conclusions}

- The studies carried out across the entire Tikhomandritsa river length, in Navolok lake waters near the river head and Udomlya lake near its mouth, as well as on the adjacent to the river earth's surface helped to identify the level of water, bottom sediments and soil contamination. Based on the studies findings it is found that:

- the water quality in Navolok lake, Tikhomandritsa river and Udomlya lake falls under contaminated category;

- bottom sediments at the upper stretch of the river up to a distance of $2.5 \mathrm{~km}$ from its origin are pure and can be used in agriculture without restriction;

- bottom sediments samples taken at a distance of $5.5 \mathrm{~km}$ from the Tikhomandritsa river head and its mouth contains dangerous level of coliform bacteria.

- Based on the area survey a plan of felling of the tree and shrubbery was drawn up and the volume of works of the river purification was determined.

- The implementation of the project of cleaning the upper stretch of the Tikhomandritsa riverbed will help to increase the river flow in dry water years, its self-cleaning velocity and environmental improvement of the area. In addition, the water flow increase into Udomlya lake will provide the Kalinin NPP with additional water resources for its process water supply. Sapropel and peat extracted from the river will be useful in agriculture.

- The conceptual scheme of this study is largely applicable in the geoecological studies of other minor river basins.

\section{Acknowledgments}

The author thanks Scientific \& Industrial Association Gidrotekhproekt for kindly providing data on the hydrological regime of the Tikhomandritsa river. Furthermore, the author is grateful to the Environmental Protection Laboratory of the Kalinin NPP and Hygiene and Epidemiology Laboratory Center (Udomlya, Tver region) for the completed laboratory tests of water, of bottom sediments and soil samples.

\section{References}

1. B.K. Vinogradov, N.A. Arkhangelsky, A.G. Korobkov et al., Udomlya district geography: Tver, Russia (Tver State University Publishing House, Tver, 1999)

2. N. Davydova, S. Servant-Wildary, Quartern. Sci. Rev. 15, 997-1012 (1996)

3. F.F. Bryukhan, A.Yu. Vinogradov, A.A.Lavrusevich, Atomic Energy 118, 365-368 (2015) 
4. Meteorological and hydrological hazards in site evaluation for nuclear installations: Specific safety guide. IAEA safety standards. No SSG-18 (IAEA Publishing House, Vienna, 2011)

5. Kalinin NPP: Preliminary material on environmental impact assessment of the Kalinin NPP power units No 2, 3 operation on the reactor facility capacity of $104 \%$ of nominal (Kalinin NPP Publishing House, Udomlya, Tver region, 2013)

6. Russian Standard SP 131.13330.2012.

7. T.S. Shelekhova, N.B. Lavrova, Proc. of the All-Russian Conf. "Geology of Karelia from the Archaean to the present», Petrozavodsk (Russia), 204-212 (2011)

8. Z. Vincevica-Gaile, M. Stapkevica, K. Stankevica, J. Burlakovs, Proc. of the Ann. 21st Int. Sci. Conf. «Research for rural development», Jelgava (Latvia), 88-94 (2015)

9. I. Ekman, V. Iljin, Deglaciation, the Young Dryas end moraine and their correlation in Russian Karelia and adjacent areas (Balkema Publishing House,Rotterdam, 1995)

10. Russian Standard SP 11-102-97

11. Russian Standard SP 47.13330.2012.

12. Russian Interstate standard GOST 17.1.5.01-80.

13. Russian Interstate standard GOST 28168-89.

14. Russian Interstate standard GOST 32861-2012

15. A.G. Muraviev, Guidelines for the determination of water quality indicators by field methods (Christmas Plus Publishing House, St. Petersburg 2009)

16. M.P. Bankin, T.A. Bankina, L.P. Korobeinikova, Physical and chemical methods in agricultural chemistry and soil biology (St. Petersburg State University Publishing House, St. Petersburg, 2005)

17. MP-4022. Microbial soil control methods: methodological recommendations (Gossanepidnadzor of Russia Publishing House, Moscow, 2004)

18. MU 2293-8. Guidelines for the sanitary-microbiological study of soils (Gossanepidnadzor of the USSR Publishing House, Moscow, 1981)

19. MUK 4.2.2661-10. Sanitary-parasitological surveys methods (Gossanepidnadzor of Russia Publishing House, Moscow, 2004)

20. Organization for Economic Co-operation and Development. Environmental policy and regulation in Russia: Implementation issue (OECD Publishing House, Paris, 2006)

21. Russian standard RD 52.24.643-2002.

22. O.V. Chernova, O.V. Beketskaya, Euras. Soil Sci. 44, 1008-1017 (2011)

23. Russian standard SanPiN 2.1.7.1287-03.

24. Z.I. Slukovskii, S.A. Svetov, Geogr. \& Nat. Res. 37, 32-38 (2016)

25. J.P.C. De Menezes, R.P. Bittencourt, M.S. De Farias et al., Revista Ambiente \& Água, 10, 748-757 (2015)

26. S. Lincheva, Y. Todorova, Y. Topalova, Biotechnol. \& Biotechnol. Eq. 28, 455-462 (2014) 